\title{
WIELKOPOLSKIE NAZWISKA MIESZKAŃCÓW MIAST ZIEM ZACHODNICH I PÓŁNOCNYCH
}

ABSTRACT. Skrodzki Miłosz, Wielkopolskie nazwiska mieszkańców miast Ziem Zachodnich i Północnych [Greater Polish surnames of the inhabitants in the cities of the West and North Territories] edited by J. Kubera, Ł. Skoczylas - „Człowiek i Społeczeństwo”, vol. XXXVII, Poznań 2014, pp. 137-148, Adam Mickiewicz University Press. ISBN 978-83-232-2764-9. ISSN 0239-3271.

The paper deals with the important, but not yet researched problem of new regions that emerged in the territories annexed to Poland after the Second World War. The removal of native inhabitants and settlement of Polish people created a radically new situation and new societies. Moreover, those large territories are varied, because people from different regions of prewar Poland came in different proportions. Then there is a need to investigate those areas and to point out new local communities. The best way to achieve this may be a research of surnames that are both strongly regional and relevant to social identity. Therefore the paper analyzes this criterion, counting the kinds of surnames originating from Greater Poland in major cities. Next it shows how those names are clustered into five distinct regions of the so-called West and North Territories.

Miłosz Skrodzki, Uniwersytet im. Adama Mickiewicza w Poznaniu, Instytut Etnologii i Antropologii Kulturowej, ul. Św. Marcin 78, 61-809 Poznań, Poland.

Po zakończeniu II wojny światowej Polska przeżyła ogromną zmianę terytorialną oraz masową migrację na niespotykaną skalę. Niemal cała ludność ziem należących przedtem do Niemiec opuściła swe rodzinne strony, a na ich miejsce przybyła znaczna część mieszkańców przedwojennej Polski. W ten sposób obszar porównywalny z powierzchnią Czech stał się widownią powstawania nowego społeczeństwa, które przez swoje wymieszanie przybrało cechy zbliżone do ogółu Polaków. Równocześnie powstawały nowe społeczności lokalne, które różniły się między sobą proporcjami osadników z różnych regionów (Sienkiewicz, Hryciuk (red.) 2008; Eberhardt 2010). W ten sposób powstał niezwykle ciekawy teren dla badań, wymagający stawienia czoła nowym problemom i zastosowania nowych narzędzi. Dotychczas teren ten pozostaje jednak niedostatecznie zbadany, a regionalne 
podziały w jego obrębie są tematem szczególnie zaniedbanym (Nitsch 1957; Gajek 1961, 1976; Urbańczyk 1962; Bohdanowicz 1987; Dejna 1993; Reichan, Woźniak 2004). Niniejszy artykuł stanowi próbę przyjrzenia się temu wielkiemu obszarowi, rozciągającemu się od północnego wschodu kraju, poprzez północny zachód, aż po południowy zachód, i wskazania odrębności regionalnych. Nie jest to jeszcze spojrzenie kompleksowe, ale swoista próba oparta na większych miastach tego obszaru jako na punktach orientacyjnych i pomiarowych, które prawdopodobnie wskazują średnie wartości dla okolicznych obszarów. W ten sposób dzieło badania regionalizacji może być rzetelnie kontynuowane, by określić ogólne ramy, które następnie można będzie uzupełniać o szczegółowe analizy lokalnych społeczności. Celem jest zatem wskazanie różnic makroregionalnych w ramach rozciągających się na setki kilometrów Ziem Zachodnich i Północnych. Zarazem będzie to ważny przyczynek do analizy samych miast, gdyż i one stanowią swoisty mikrokosmos, choć w tym przypadku podział pomiędzy nimi a prowincją jest mniejszy niż zazwyczaj, bo i tu, i tam praktycznie cała ludność przybyła w wyniku masowej migracji.

Kryterium wyznaczania społecznej specyfiki będą $\mathrm{w}$ tym przypadku nazwiska. Ich znaczenie dla tożsamości kulturowej i regionalnej było podnoszone już wielokrotnie, ale jak dotąd brakło danych, które mogłyby być wykorzystane do sformułowania wiążących wniosków (Taszycki 1924; Rospond 1967; Bubak 1986; Bystroń 1993; Kaleta 1998; Rymut 1999-2002; Breza 2000-2004; Skowronek 2001). W ostatnim czasie, dzięki Powszechnemu Elektronicznemu Systemowi Ewidencji Ludności, stało się to jednak możliwe. Najpełniejsze dane pozyskał i opublikował Kazimierz Rymut, który podał frekwencję wszystkich nazwisk w każdym z obecnych powiatów (Rymut 2003). W ten sposób można zbadać proporcje nazwisk różnych typów, pochodzących z różnych regionów przedwojennej Polski, we wszystkich miastach na prawach powiatu, których na badanym obszarze jest 18. Są to kolejno, zaczynając od północnego wschodu: Olsztyn, Elbląg, Gdańsk, Sopot, Słupsk, Koszalin, Świnoujście, Szczecin, Gorzów Wielkopolski, Zielona Góra, Legnica, Jelenia Góra, Wałbrzych ${ }^{1}$, Wrocław, Opole, Gliwice, Zabrze i Bytom. Spośród nich trzy największe (Gdańsk, Szczecin i Wrocław) liczą powyżej 400 tys. mieszkańców, dwa najmniejsze (Sopot i Świnoujście) około 40 tys., a pozostałe przeważnie nieco ponad 100 tys. - jedynie Olsztyn i trzy miasta konurbacji górnośląskiej mają około 200 tys. mieszkańców (Rymut 2003: 10-17). Różnice te są o tyle ważne, że mogą pomóc w procedurze

\footnotetext{
${ }^{1}$ Obecnie Wałbrzych utracił prawa powiatu grodzkiego, natomiast początkowo takie miał i słownik Rymuta jeszcze uwzględnia tę jego odrębność.
} 
badania regionalizacji: miasta największe jako najbardziej miarodajne powinny bowiem stanowić oparcie, natomiast te najmniejsze są obarczone największym ryzykiem przypadkowych wahań.

Dla jasności badanej próby i ze względów praktycznych brane będą pod uwagę tylko nazwiska $\mathrm{z}$ grupy tysiąca najczęstszych $\mathrm{w}$ skali kraju, wedle oficjalnej listy rządowej upublicznionej w tym samym czasie co dane dotyczące powiatów (Zawadzki 2002: 292-303). Ze względu na ogrom materiału $\mathrm{w}$ niniejszym artykule zakres badania ograniczony zostanie ponad to do tych nazwisk, które można uznać za typowo wielkopolskie, co poprzez wykazanie niedoborów pozwoli jednak równocześnie wskazać te miasta, gdzie napłynęła zapewne przede wszystkim ludność z innych regionów przedwojennej Polski. Zasadniczym problemem jest $\mathrm{w}$ tej sytuacji wyróżnienie tych rodzajów nazwisk, które można uznać za wielkopolskie. Przystępując do tego zadania, trzeba najpierw określić obszar, jaki z możliwie największą dozą prawdopodobieństwa da się określić jako wielkopolski. Ogólnie przyjętym punktem odniesienia jest tu $\mathrm{w}$ pierwszej kolejności województwo o takiej nazwie. Jeśli dziś mówi się o Wielkopolsce, to najpowszechniejszym skojarzeniem jest właśnie ta jednostka administracyjna. Nie pokrywa się ona ściśle z krainą historyczną ani z regionem etnograficznym, ale można przyjąć, że wykazuje najwięcej cech wielkopolskich (Burszta 1960-1967; Sobierajski, Burszta 1979-2005; Brencz 1996). W istocie, jej kształt jest wypadkową tego, co określano mianem Wielkopolski w różnych okresach - przed rozbiorami, pod zaborami, w międzywojniu oraz po wojnie. $W$ odniesieniu do obecnych województw nie sporządzono tak obszernej listy najpopularniejszych nazwisk, jak to uczyniono na prośbę Jarosława Macieja Zawadzkiego dla całego terytorium państwa. Niemniej samo Ministerstwo Spraw Wewnętrznych i Administracji ze swej strony upubliczniło skromne co prawda, ale wystarczające dla rozstrzygnięcia omawianej kwestii dane. Jest to ranking dziesięciu najczęstszych nazwisk w każdym z województw, podający ich frekwencję w liczbach bezwzględnych. Mimo że województwo wielkopolskie należy do największych i położone jest blisko centrum, już na tym poziomie uwidacznia się jego specyfika (tab. 1).

Ze względu na to, że pierwsze dziesiątki obu płci różnią się jedną pozycją, wartości w nawiasach kwadratowych są orientacyjne (miejsce dziesiąte $\mathrm{w}$ danej płci pomniejszone o jedność). Odsetek podany w ostatniej kolumnie oznacza stosunek populacji osób noszących dane nazwisko w województwie wielkopolskim do populacji osób o tym samym nazwisku w całym kraju. Przy czym istotny dla dalszych rozważań jest fakt, że procentowy udział całej populacji wielkopolskiej w populacji krajowej (dalej: PUPW - procentowy udziat populacji wielkopolskiej) wynosił wówczas ok. 9\%. 
Tabela 1. Najczęstsze nazwiska w województwie wielkopolskim na tle Polski

\begin{tabular}{|l|c|c|c|c|c|}
\hline \multicolumn{1}{|c|}{ Nazwisko } & Kobiety & Mężczyźni & Ogółem & Polska & Odsetek \\
\hline Nowak & 17940 & 17071 & 35011 & 203506 & $17 \%$ \\
\hline Kaczmarek & 12368 & 11817 & 24185 & 61816 & $39 \%$ \\
\hline Wojciechowski & 6670 & 6258 & 12928 & 66361 & $19 \%$ \\
\hline Woźniak & 6476 & 6258 & 12734 & 88039 & $14 \%$ \\
\hline Kowalski & 6366 & 6141 & 12507 & 139719 & $9 \%$ \\
\hline Szymański & 6268 & 6061 & 12329 & 89091 & $14 \%$ \\
\hline Ratajczak & 5734 & 5442 & 11176 & 17280 & $65 \%$ \\
\hline Michalak & 5493 & 5290 & 10783 & 42405 & $25 \%$ \\
\hline Kubiak & 5481 & 5125 & 10606 & 32171 & $33 \%$ \\
\hline Pawlak & {$[5322]$} & 5142 & 10464 & 45218 & $23 \%$ \\
\hline Wiśniewski & 5323 & {$[5124]$} & 10447 & 109855 & $10 \%$ \\
\hline
\end{tabular}

Źródło: Zawadzki 2002; MSWiA 2004.

Zgodnie z tymi danymi najbardziej charakterystyczną dla Wielkopolski grupę nazwisk stanowią te odimienne $\mathrm{z}$ przyrostkiem -ak². Procentowy udział osób o nazwisku Michalak, Kubiak i Pawlak jest trzykrotnie większy od PUPW. Typowe dla Wielkopolski są z pewnością również nazwiska z przyrostkiem -ak utworzone od nazw zawodów ${ }^{3}$. Woźniak ma co prawda mniej niż dwa PUPW, ale za to Ratajczak bije wszelkie rekordy koncentracji. Czterokrotnie częstsze niż PUPW jest nazwisko Kaczmarek, które jak widać, niebezzasadnie uznawane jest $\mathrm{w}$ potocznej opinii za typowo wielkopolskie. Z drugiej strony należy zachować pewną ostrożność, gdyż w pierwszej jedenastce nie ma więcej nazwisk pochodzących od zawodów z dodaniem przyrostka -ek ${ }^{4}$. W sumie więc na pewno trzeba się będzie przyjrzeć i tej grupie nazwisk, choć tutaj mogą się pojawić rozbieżności. Szczególnie wiele trudności sprawia nazwisko Nowak. Nie sposób go pominąć, gdyż przekracza ono PUPW dwukrotnie, choć biorąc pod uwage jego liczebność w skali kraju, trudno zakładać, że jest typowe tylko dla tego regionu. Problemem jest jednak przede wszystkim sama typologia tego nazwiska, która wiąże się

2 Typ nazwisk odimiennych jest zaliczany do podstawowych. Również przyrostek -ak uznaje się za jeden $z$ najczęstszych w polskich nazwiskach (Rospond 1967: XXI; Bubak 1986: 91-93; Bystroń 1993: 25-26; Skowronek 2001: 140-141).

${ }^{3}$ Niektórzy autorzy nie wydzielają osobnej grupy nazwisk pochodzących od zawodów, zaliczając je ogólnie do odapelatywnych. Niemniej w świetle powyższych danych, a także argumentów wyłożonych obszernie przez Józefa Bubaka (1986: 39-43, 156-158) oraz w pionierskiej pracy Witolda Taszyckiego (1924: 4-5, 13-14), należy taką grupę wyodrębnić, przynajmniej w tym przypadku.

${ }^{4}$ Przyrostek ten, podobnie jak -ak, zaliczany jest do najważniejszych (Rospond 1967; Bubak 1986: 81-84; Skowronek 2001: 141-142). 
z jego nadzwyczajną popularnością. Ta uniwersalność utrudnia wskazanie grupy nazwisk podobnych, którą można by przeanalizować. Mogłyby to być zbliżone znaczeniowo nazwiska z przyrostkiem -ak, ale wśród tysiąca najczęstszych nie sposób jest takie znaleźć. $W$ tej sytuacji jedynym wyjściem jest wzięcie pod uwagę wszystkich nazwisk pochodzących od nowy, których jest już sporo i które wykazują znaczną liczebność 5 . W okolicach dwóch PUPW utrzymują się również nazwiska odimienne z przyrostkiem -ski (Wojciechowski i Szymański) ${ }^{6}$. Je również można zatem uznać za raczej typowe dla Wielkopolski, choć nie jest to już tak pewne, jak choćby w przypadku odimiennych zakończonych na -ak. Natomiast pozostałe dwa nazwiska trudno uznać za rdzennie wielkopolskie ze względu na to, że ich odsetek w województwie jest zbliżony do PUPW; nie da się ich również przyporządkować do żadnej z wymienionych wyżej grup.

W ten sposób można wyróżnić pięć głównych typów wielkopolskich nazwisk. Podstawowym są odimienne z przyrostkiem -ak, których wśród tysiąca najczęstszych można naliczyć aż 74. Są to: Adamczak, Adamiak, Ambroziak, Andrzejczak, Antczak, Augustyniak, Balcerzak, Banasiak, Banaszak, Bartczak, Bartkowiak, Błaszczak, Dominiak, Filipiak, Florczak, Frąckowiak, Frątczak, Grzelak, Grzesiak, Grześkowiak, Jakubiak, Janczak, Janiak, Jankowiak, Jędrzejczak, Jóźwiak, Jurczak, Juszczak, Kacprzak, Karolak, Kasprzak, Kazimierczak, Kaźmierczak, Klimczak, Krysiak, Kubiak, Łuczak, Maćkowiak, Majchrzak, Marciniak, Marczak, Matusiak, Matuszak, Matysiak, Michalak, Mikołajczak, Misiak, Olczak, Olszak, Pawlak, Pietrzak, Rosiak, Roszak, Sobczak, Stachowiak, Stańczak, Stasiak, Staszak, Stefaniak, Szczepaniak, Szcześniak, Szymaniak, Szymczak, Szymkowiak, Tomczak, Urbaniak, Wachowiak, Walczak, Walkowiak, Wasiak, Wawrzyniak, Witczak, Wojtczak oraz Wojtkowiak (Rymut 1999-2001; Zawadzki 2002)7.

Mniej liczną grupą są nazwiska pochodzące od zawodów z dodaniem tego samego przyrostka, których jest 10: Cieślak, Dudziak, Kołodziejczak, Ławniczak, Olejniczak, Ratajczak, Skrzypczak, Sołtysiak, Woźniak i Wójciak (Rymut 1999-2001; Zawadzki 2002) ${ }^{8}$.

${ }^{5}$ Szerzej na ten temat: Bystroń 1993.

${ }^{6}$ Sufiks -ski uważa się za najpowszechniejszy wśród polskich nazwisk (Skowronek 2001: 154-155)

7 Nie wszystkie $z$ tych form są pewne, gdyż często zachodziły tu gwarowe i fonetyczne przekształcenia (np. Misiak może pochodzić od imion Michał lub Mikołaj, ale również od apelatywu miś).

8 Pominięto tutaj nazwisko Królak, które ma charakter wybitnie przezwiskowy (trudno przypuszczać, aby noszące je osoby pochodziły z królewskiej dynastii), a także Żak oraz Rybak i Śpiewak, które nie zostały utworzone za pomocą przyrostka -ak (w pierwszym w ogóle go nie ma, a w dwóch kolejnych był on już integralną częścią nazwy zawodu). 
Również 10 nazwisk jest utworzonych od nazw zawodów z przyrostkiem -ek: Bednarek, Kaczmarek, Mielcarek, Mielczarek, Milczarek, Owczarek, Pisarek, Smolarek, Szkudlarek i Zdunek (Rymut 1999-2001; Zawadzki 2002) $)^{9}$.

Nazwisk pochodzących od nowy jest wśród tysiąca 6: Nowacki, Nowaczyk, Nowak, Nowakowski, Nowicki i Nowiński (Rymut 1999-2001; Zawadzki 2002). $Z$ kolei aż 55 nazwisk to odimienne z przyrostkiem -ski: Adamczewski, Adamski, Andrzejewski, Bieńkowski, Biernacki, Bogdański, Domański, Frankowski, Iwański, Jackowski, Jakubowski, Janicki, Janiszewski, Jankowski, Janowski, Januszewski, Jaroszewski, Jędrzejewski, Kaźmierski, Kubacki, Kubicki, Łukaszewski, Maciejewski, Marcinkowski, Markowski, Matuszewski, Michalski, Michałowski, Mikulski, Pawlicki, Pawlikowski, Pawłowski, Piechocki, Piotrowski, Radecki, Romanowski, Romański, Sawicki, Sobański, Stachowski, Stachurski, Stanisławski, Staniszewski, Staszewski, Stefański, Sułkowski, Szczepański, Szymański, Tomaszewski, Urbański, Wasielewski, Wasilewski, Więckowski, Witkowski oraz Wojciechowski (Rymut 1999-2001; Zawadzki 2002) ${ }^{10}$.

Rozkład badanej próby $\mathrm{w}$ poszczególnych miastach przedstawiono w tabeli 2.

Analizę należy rozpocząć od pierwszej kolumny, w której znajduje się typ zarówno najbardziej wielkopolski, jak i - obok ostatniego - najliczniejszy, czyli nazwiska odimienne z przyrostkiem -ak. Jeśli chodzi o miasta największe, to pierwsze miejsce zajmuje Szczecin, który ma ich nieco więcej niż Wrocław i o połowę więcej niż Gdańsk. Już w pierwszej chwili widać także, że poziom zbliżony do pierwszego z nich wykazują sąsiednie Świnoujście i Koszalin, natomiast do ostatniego podobne są pobliskie Sopot i Słupsk, a także Elbląg i Olsztyn. Nieco inaczej sytuacja przedstawia się na terytorium określanym zwykle jako Dolny Śląsk, w skupisku czterech miast, z Wrocławiem na czele. O ile Wałbrzych ma wartość nieco wyższą od stolicy regionu (podobną do dalekiego Szczecina), o tyle Jelenia Góra ma nieco, a Legnica nawet znacznie mniej (ta ostatnia tyle co Gdańsk). Zdecydowanie najwyższy poziom (dwukrotność liczby wystąpień z Gdańska) wykazują dwa miasta położone tuż na zachód od Wielkopolski: Gorzów Wielkopolski i Zielona Góra, natomiast najniższy (połowę liczby wystąpień ze Szczecina) -

${ }_{9} \mathrm{Z}$ tych samych przyczyn jak w przypadku przyrostka -ak pominięto tutaj nazwiska Książek, Marszałek i Panek oraz Piszczek i Skrzypek.

10 Pominięto tutaj takie nazwiska jak Bogucki, które są częściowo odimienne, a częściowo odmiejscowe i w przypadku których trudno stwierdzić, jaka geneza przeważa wśród współczesnych nosicieli (tu np. dwa skupiska: wokół zaścianka szlacheckiego Boguty oraz miejscowości pod Warszawą). 
Tabela 2. Odsetek osób z nazwiskami z listy tysiąca najczęstszych należących do typów wielkopolskich $\mathrm{w}$ miastach na prawach powiatu przyłączonych do Polski po II wojnie światowej

\begin{tabular}{|c|c|c|c|c|c|}
\hline \multirow{2}{*}{ Miasto } & \multicolumn{5}{|c|}{$\begin{array}{c}\text { Rodzaje nazwisk } \\
\text { (w \%) }\end{array}$} \\
\hline & $\begin{array}{l}\text { imię } \\
\text {-ak }\end{array}$ & $\begin{array}{c}\text { zawód } \\
\text {-ak }\end{array}$ & $\begin{array}{l}\text { zawód } \\
\text {-ek }\end{array}$ & $\begin{array}{c}\text { pochodzące } \\
\text { od przymiotnika nowy }\end{array}$ & $\begin{array}{l}\text { imię } \\
\text {-ski }\end{array}$ \\
\hline Olsztyn & 1,6 & 0,23 & 0,21 & 0,53 & 3,8 \\
\hline Elbląg & 1,8 & 0,29 & 0,19 & 0,69 & 3,7 \\
\hline Gdańsk & 1,9 & 0,36 & 0,29 & 0,66 & 3,7 \\
\hline Sopot & 2,0 & 0,41 & 0,28 & 0,67 & 3,4 \\
\hline Słupsk & 2,1 & 0,34 & 0,48 & 0,77 & 3,4 \\
\hline Koszalin & 2,8 & 0,50 & 0,36 & 0,84 & 3,6 \\
\hline Świnoujście & 3,1 & 0,47 & 0,35 & 0,87 & 3,5 \\
\hline Szczecin & 3,0 & 0,50 & 0,41 & 0,88 & 3,7 \\
\hline $\begin{array}{l}\text { Gorzów } \\
\text { Wielkopolski }\end{array}$ & 3,8 & 0,73 & 0,66 & 1,09 & 3,9 \\
\hline Zielona Góra & 3,8 & 0,88 & 0,55 & 1,03 & 3,8 \\
\hline Legnica & 2,0 & 0,33 & 0,30 & 0,63 & 2,7 \\
\hline Jelenia Góra & 2,3 & 0,39 & 0,35 & 0,77 & 3,0 \\
\hline Wałbrzych & 2,9 & 0,64 & 0,42 & 1,00 & 3,2 \\
\hline Wrocław & 2,6 & 0,45 & 0,44 & 0,88 & 3,0 \\
\hline Opole & 1,6 & 0,36 & 0,28 & 0,75 & 2,4 \\
\hline Gliwice & 1,4 & 0,31 & 0,28 & 0,83 & 2,3 \\
\hline Zabrze & 1,5 & 0,31 & 0,35 & 1,03 & 2,2 \\
\hline Bytom & 1,6 & 0,33 & 0,39 & 1,14 & 2,0 \\
\hline
\end{tabular}

Kolejność miast: od północnego wschodu, poprzez północny zachód, po południowy zachód.

Źródło: Zawadzki 2002; Rymut 2003; obliczenia własne.

pozostałe cztery, położone na Górnym Śląsku, gdzie po wojnie nie nastąpiła wymiana ludności. W ten sposób rysuje się już wyraźna hierarchia, która ma charakter wybitnie regionalny, i jedynie Dolny Śląsk wykazuje nieco większe zróżnicowanie wewnętrzne, ale zarazem pozostaje wyraźnie odrębny od terenów sąsiednich. Niemniej jednak, aby obraz mógł być pełny, należy porównać ten typ, który można uznać za główny, z pozostałymi, mogącymi ten obraz uzupełnić lub skorygować.

$\mathrm{W}$ przypadku nazwisk $\mathrm{z}$ tym samym przyrostkiem -ak, ale pochodzących od zawodów, obraz jest bardzo podobny do odimiennych. Powtarzają się więc przede wszystkim proporcje pomiędzy trzema największymi miastami. Powtarza się również pokrewieństwo pomiędzy Szczecinem a Kosza- 
linem i Świnoujściem oraz pomiędzy Gdańskiem a Słupskiem i Sopotem, choć $\mathrm{w}$ tym ostatnim daje się zauważyć pewne odchylenie związane z niewielką populacją tego miasta i liczebnością badanego typu. Większą niż w przypadku nazwisk odimiennych różnicę w stosunku do Gdańska wykazują: Elbląg oraz (zwłaszcza) Olsztyn. Kolejność rankingowa powtarza się na Dolnym Śląsku, z tym że Wałbrzych odznacza się wartością jeszcze wyższą niż poprzednio, przekraczającą znacznie nawet Szczecin. Miasto to pozostaje jednak w tyle za Gorzowem i szczególnie Zieloną Górą, która również wykazuje wyjątkowo zwiększony poziom. Z kolei jeśli chodzi o Górny Śląsk, to odznacza się on odsetkiem zbliżonym do Gdańska oraz nieco wyższym niż Olsztyn i Elbląg. Ogólnie można zatem powiedzieć, że obraz dotyczący bardziej licznych nazwisk odimiennych powtarza się, z wyjątkiem paru niuansów, mianowicie nieco większej obecności w Zielonej Górze, Wałbrzychu i na Górnym Śląsku, a także nieco mniejszej na wschód od Wisły.

Jeśli chodzi o nazwiska pochodzące od zawodów, ale utworzone za pomocą przyrostka -ek, sprawa wygląda dość podobnie. Szczecin wraz ze Świnoujściem i Koszalinem mają ich znacznie więcej niż Gdańsk z Sopotem, jedynie Słupsk ma wartość znacznie zwiększoną, wyższą nawet niż Szczecin. Podobnie jak $\mathrm{w}$ poprzedniej grupie, dość wyraźnie rysuje się ponadto przedział pomiędzy Gdańskiem a miastami dalej na wschód. Wartości rozciągające się od Gdańska po Szczecin wykazują również miasta Dolnego Śląska, w kolejności od Legnicy po Wrocław i Wałbrzych. Najwyższe wartości przyjmuje jak zwykle Lubuskie, z tym że tym razem to Gorzów przewyższa Zieloną Górę. Najbardziej zwiększone wartości - obok Słupska - wykazują zaś miasta Górnego Śląska, a zwłaszcza dwa najbardziej wysunięte na wschód, które dochodzą aż do poziomu Szczecina.

Dość szczególną grupę stanowią nazwiska utworzone od przymiotnika nowy. W zasadzie, z niewielkimi wahaniami i poza jednym wyjątkiem, rozkład geograficzny i tutaj pokrywa się z typem podstawowym. Tu również Szczecin ma wyraźnie wyższy poziom niż Gdańsk, pary miast pomiędzy nimi są do nich zbliżone, miasta Dolnego Śląska układają się pomiędzy nimi, a Lubuskie ma wartości jeszcze wyższe, z kolei najmniej ma Warmińsko-Mazurskie. Można jedynie odnotować, że Elbląg i Słupsk mają odsetek nieco zwiększony, a Lubuskie i w pewnym stopniu Pomorze Zachodnie - nieco zmniejszony. Jedyną znaczącą różnicę wykazuje znów Górny Śląsk, który tym razem przyjmuje już wartości bardzo wysokie, a zarazem ponownie wykazuje zróżnicowanie na linii wschód-zachód. O ile więc Opole ma jeszcze poziom niższy niż Szczecin i Wrocław, to Gliwice już się do nich zbliżają i w końcu Zabrze, a zwłaszcza Bytom znacznie je przekraczają, upodobniając się poziomem do Lubuskiego. 
Pozostaje jeszcze ostatni typ, bardzo liczny, ale raczej nie aż tak bardzo wielkopolski - nazwiska odimienne $\mathrm{z}$ przyrostkiem -ski. W ich przypadku widać dość znaczne przesunięcia, i to $\mathrm{w}$ innych kierunkach niż poprzednio, choć zachodzące $\mathrm{w}$ ramach podobnych regionów. Przede wszystkim Gdańsk awansuje do poziomu Szczecina, przewyższając tym samym Wrocław. Wraz z wielkim miastem przy ujściu Wisły zwiększają się także wartości w Sopocie i Słupsku, a zwłaszcza w Olsztynie i Elblągu. Koszalin i Świnoujście pozostają na poziomie Szczecina, a Dolny Śląsk utrzymuje swoją hierarchię w stosunku do Wrocławia, choć i tu daje się zauważyć pewne zniwelowanie różnic. Maleje natomiast poziom miast lubuskich i w ten sposób następuje praktycznie wyrównanie poziomu od Zielonej Góry aż do Olsztyna. Jeśli zaś chodzi o pozostałe miasta, to Górny Śląsk znów wykazuje wewnętrzną spójność - jego miasta dość zgodnie przybliżają się bowiem nieco do Dolnego Śląska. Ogólnie rzecz biorąc, widać zatem pewną odrębność tego typu, który już ze względu na zrównanie Warmii i Mazur z Lubuskiem trudno uznać za czysto wielkopolski, i dlatego też jego znaczna liczebność porównywalna z nazwiskami odimiennymi z przyrostkiem -ak nie może iść $w$ parze $z$ uznaniem równej wagi ich obu dla badanego problemu.

W świetle powyższych danych widać przede wszystkim znaczny napływ ludności wielkopolskiej bezpośrednio na zachód, na tereny przyłączone nawet początkowo do województwa poznańskiego, a później wydzielone w inne jednostki administracyjne. Warto przy tym zauważyć, że Wrocław czy Legnica, które leżą $\mathrm{w}$ podobnej odległości od granic przedwojennej Wielkopolski, mają już o wiele niższe wskaźniki, z czego wynika wniosek, że ludność z Wielkopolski przemieszczała się nie tyle na obszary najbliższe, ile raczej w kierunku zachodnim. Niemniej odległość w linii prostej także odgrywała pewną rolę, co widać choćby po dość wysokich wynikach Wrocławia na tle miast dolnośląskich. Zarazem znaczną rolę odgrywać musiał także przebieg szlaków komunikacyjnych, a zwłaszcza linii kolejowych, co mogłoby tłumaczyć jeszcze wyższe odsetki w Wałbrzychu, a także lepsze wyniki Jeleniej Góry niż Legnicy.

Wracając do samych regionów, najwyższy odsetek ludności wielkopolskiej wykazuje ten, do którego po wojnie przylgnęła nazwa Lubuskie. Jak widać, przyjęty w tym samym okresie przydomek Gorzowa nie był przypadkowy, choć w równym stopniu należałby się on także Zielonej Górze. Również Dolny Śląsk, który został w praktyce uznany za odrębny region, pokrywający się z granicami województwa, ze stolicą we Wrocławiu, potwierdza tutaj swą specyfikę, a mianowicie znacznie niższe wskaźniki niż w Lubuskiem, ale i wyższe niż na Górnym Śląsku. Jeśli zaś chodzi o ten ostatni, to również on wykazuje dość dużą spójność oraz odrębność od 
wszystkich ziem przyłączonych do Polski, wynikające z faktu, że nie nastąpiła tutaj wymiana ludności. Należy jednak zaznaczyć, że i na tym obszarze odsetek ludności wielkopolskiej jest stosunkowo wysoki, co jest zapewne skutkiem bardzo dużej migracji do ośrodków przemysłowych na przestrzeni XIX i XX stulecia. Odrębność tego regionu wyraża się ponadto we względnie mniejszym odsetku typu głównego, natomiast znacznie wyższym - nazwisk pochodzących od zawodów z przyrostkiem -ek, a zwłaszcza utworzonych od przymiotnika nowy, przy czym nadwyżki te są większe we wschodniej części regionu. Zarazem warto podkreślić integralną przynależność do niego także Opola, z którym Gliwice - ze względu na te właśnie nadwyżki - mają nawet więcej wspólnego niż z niemalże przyległym Bytomiem.

Jeśli zaś chodzi o miasta położone na północy, to przede wszystkim rysuje się przewaga regionu nazywanego najczęściej Pomorzem Zachodnim nad miastami położonymi dalej na wschód, od Słupska aż po Olsztyn (poza nazwiskami odimiennymi z przyrostkiem -ski). Może nieco dziwić tak bliskie pokrewieństwo Słupska i Gdańska, oddzielonych przecież przed wojną terytorium Polski, ale w dużej mierze to właśnie Kaszuby stały się po wojnie ich zwornikiem, do obu miast napłynęła bowiem w dużym stopniu ludność z tego przyległego regionu, co zmniejszyło z pewnością odsetek Wielkopolan. Zarazem można jednak wskazać pewną autonomię Słupska, widoczną przede wszystkim $w$ nazwiskach utworzonych przez dodanie do nazwy zawodu przyrostka -ek. Z drugiej strony rysuje się także odrębność Elbląga oraz (zwłaszcza) Olsztyna, które mają wskaźniki nieco niższe od Gdańska, zwłaszcza w przypadku obu typów pochodzących od zawodów, przy czym najmniej wielkopolskich nazwisk odimiennych zakończonych na -ski mają tyle samo lub nawet więcej. Wygląda zatem na to, że im dalej na wschód, tym Wielkopolan przybywało nieco mniej, a za swoiste słupy graniczne można uznać Kaszuby oraz Wisłę. Tak czy inaczej, przedziały te nie mogą się równać z regularną przepaścią, jaka dzieli Pomorze położone bliżej Szczecina od jego części w pobliżu Gdańska.

Tym samym okazuje się, że tereny sięgające od Olsztyna, poprzez Gdańsk, Szczecin i Wrocław, aż po Bytom, określane zbiorczo jako Ziemie Zachodnie i Północne, wykazują w swoim obrębie duże zróżnicowanie wynikające z różnych kierunków migracji po wojnie. Różnice pomiędzy obszarami, gdzie przybyło najwięcej i najmniej ludności wielkopolskiej, są około dwukrotne, a czasami nawet większe. Zarazem okazuje się, że dość intuicyjnie wyznaczane regiony, które przyjęły się na przestrzeni ostatnich kilkudziesięciu lat - także jako jednostki administracyjne - w dużej mierze znajdują swoje potwierdzenie. W pierwszej kolejności jako teren migracji Wielkopolan oraz ich nazwisk wyróżnia się Lubuskie (Gorzów nomen omen Wielkopolski 


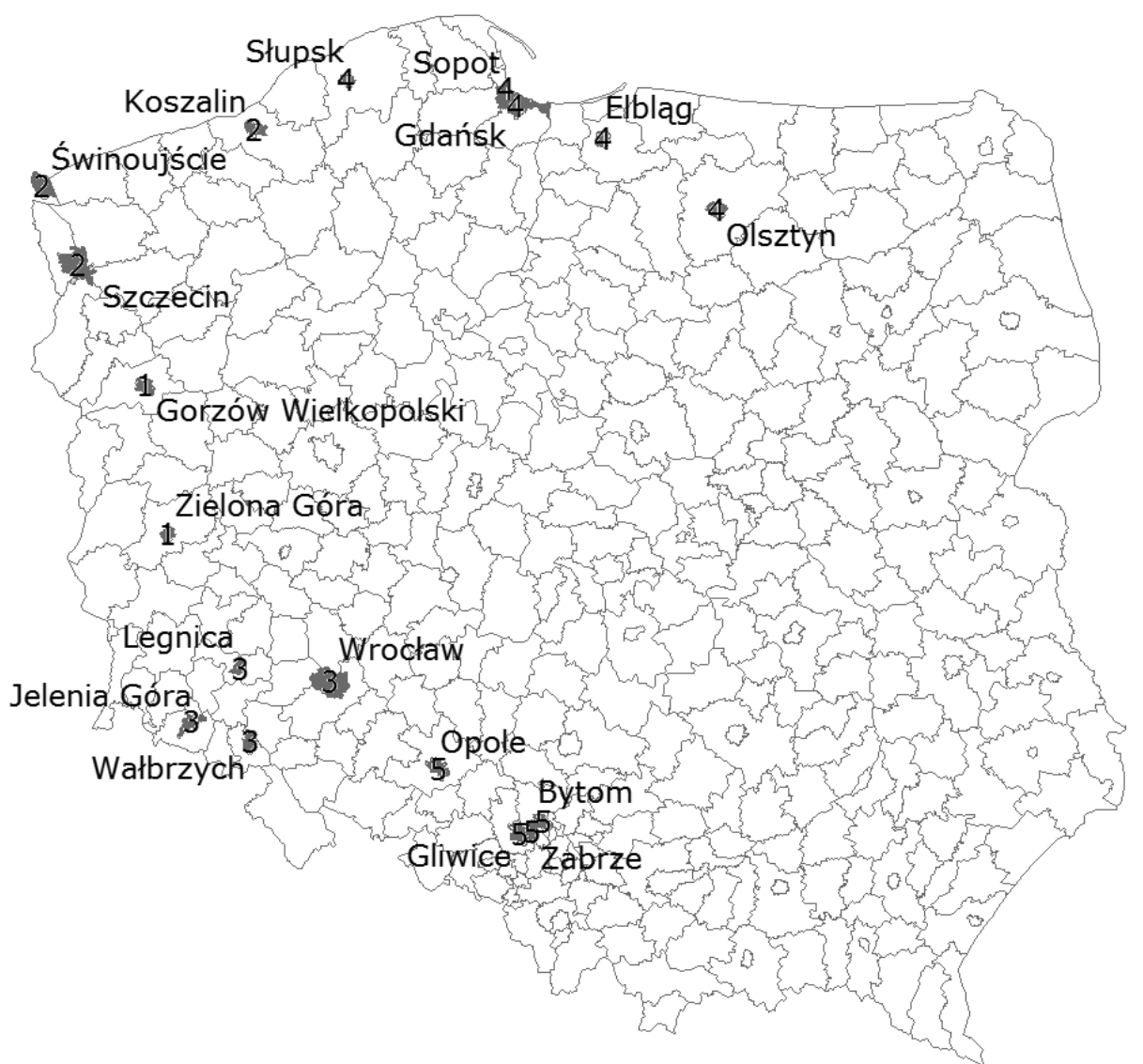

Legenda: 1 - region lubuski, 2 - region zachodniopomorski, 3 - region dolnośląski, 4 - region wschodniopomorski, 5 - region górnośląski.

Rycina. Przynależność regionalna miast wydzielonych na Ziemiach Zachodnich i Północnych

Źródło: Opracowanie własne na podstawie szablonu powiatów z Wikimedia Commons.

i Zielona Góra), na drugim miejscu znajduje się Pomorze Zachodnie (Koszalin, Świnoujście i Szczecin), a jeszcze mniej mają tereny, które można nazwać ogólnie Pomorzem Wschodnim (Olsztyn, Elbląg, Gdańsk, Sopot i Słupsk). Wartości pomiędzy obiema częściami Pomorza przyjmuje Dolny Śląsk (Legnica, Jelenia Góra, Wałbrzych i Wrocław), natomiast najniższe - Górny Śląsk (Opole, Gliwice, Zabrze i Bytom). W ten sposób przedstawia się hierarchia pięciu regionów o odmiennym charakterze migracji - regionów, które powstały właśnie dzięki migracjom i których miasta są sobie bardzo bliskie nie tylko geograficznie, ale i społecznie. 


\section{BIBLIOGRAFIA}

Bohdanowicz J. (1987), Regiony etnograficzne Polski w świetle wyników badań "Polskiego atlasu etnograficznego", „Etnografia Polska” nr 31(2).

Brencz A. (1996), Wielkopolska jako region etnograficzny, Wydawnictwo Naukowe UAM, Poznań.

Breza E. (2000-2004), Nazwiska Pomorzan. Pochodzenie i zmiany, t. 1-3, Wydawnictwo Uniwersytetu Gdańskiego, Gdańsk.

Bubak J. (1986), Proces kształtowania się polskiego nazwiska mieszczańskiego i chłopskiego, Wydawnictwo Uniwersytetu Jagiellońskiego, Kraków.

Burszta J., red. (1960-1967), Kultura ludowa Wielkopolski, t. 1-3, Wydawnictwo Poznańskie, Poznań.

Bystroń J.S. (1993), Nazwiska polskie, Książka i Wiedza, Warszawa.

Dejna K. (1993), Dialekty polskie, Ossolineum, Wrocław.

Eberhardt P. (2010), Migracje polityczne na ziemiach polskich (1939-1950), Instytut Zachodni, Poznań.

Gajek J. (1961), Studia nad etnograficzną regionalizacją Polski, „Lud” nr 4.

Gajek J. (1976), Etnograficzne zróżnicowanie obszaru Polski, [w:] Etnografia Polski. Przemiany kultury ludowej, t. 1, red. M. Biernacka, Ossolineum - PAN, Wrocław.

Kaleta Z. (1998), Nazwisko w kulturze polskiej, Slawistyczny Ośrodek Wydawniczy, Warszawa.

MSWiA (2004), Statystyka najpopularniejszych nazwisk w Polsce w podziale na województwa $i$ płeć - bez zgonów, wyjazdów i wymeldowań. Stan na listopad 2004, http://www. msw.gov.pl/download.php?s=1\&id=1022 [dostęp: 1.09.2009].

Nitsch K. (1957), Dialekty języka polskiego, Ossolineum, Wrocław.

Reichan J., Woźniak K. (2004), Polskie atlasy dialektologiczne i etnograficzne, Lexis, Kraków.

Rospond S. (1967), Stownik nazwisk ślaskich, cz. 1, Ossolineum, Wrocław.

Rymut K. (1999-2001), Nazwiska Polaków. Stownik historyczno-etymologiczny, t. 1-2, Instytut Języka Polskiego PAN, Kraków.

Rymut K., opr. (2003), Stownik nazwisk używanych w Polsce na poczatku XXI wieku, Instytut Języka Polskiego PAN, Kraków.

Sienkiewicz W., Hryciuk G., red. (2008), Wysiedlenia, wypędzenia i ucieczki 1939-1959. Atlas ziem Polski. Polacy, Żydzi, Niemcy, Ukraińcy, Demart, Warszawa.

Skowronek K. (2001), Wspótczesne nazwisko polskie. Studium statystyczno-kognitywne, Wydawnictwo Naukowe DWN, Kraków.

Sobierajski Z., Burszta J., red. (1979-2005), Atlas języka i kultury ludowej Wielkopolski, t. 1-11, Ossolineum - Wydawnictwo Naukowe UAM, Wrocław - Poznań.

Taszycki W. (1924), Polskie nazwy osobowe, Gebethner i Wolff, Kraków.

Urbańczyk S. (1962), Zarys dialektologii polskiej, PWN, Warszawa.

Zawadzki J.M. (2002), Tysiąc najpopularniejszych nazwisk w Polsce, Bertelsmann Media, Warszawa. 